\title{
PENGEMBANGAN SENAM HAMIL DAN PENGARUHNYA TERHADAP PENGURANGAN KELUHAN NYERI PINGGANG PADA IBU HAMIL TRIMESTER III
}

\section{DEVELOPMENT OF PREGNANT GYMNASTIC AND ITS EFFECT ON REDUCING WAIST PAIN COMPLAINTS IN MOTHER PREGNANCY THIRD TRIMESTER}

\author{
Neny Yuli Susanti ${ }^{1}$, Nurul Khalifah Putri ${ }^{2}$ \\ Prodi DIII Kebidanan, Fakultas Ilmu Kesehatan, Universitas Ibrahimy \\ ${ }^{1}$ Email: nenyyulisusanti@gmail.com
}

\begin{abstract}
ABSTRAK
Salah satu faktor penyebab nyeri punggung bawah pada wanita hamil adalah tekanan pada otot punggung atau pergeseran tulang belakang bawah, stres sendi ini dapat ditangani dengan senam hamil selama 30 menit. Tujuan penelitian ini adalah mnngetahui pengaruh pengembangan senam hamil untuk menurunkan lebih rendah nyeri punggung pada wanita hamil. Desain Penelitian Pra-Eksperimental menggunakan uji sebelum dan sesudah dalam satu kelompok. Metode Sampling yang digunakan Purposive Sampling. Sampel terdiri dari 14 responden di desa sumberejo kecamatan banyuputih situbondo pada bulan Mei. Data diambil dari wawancara dan observasi pada ibu hamil. Data dianalisis menggunakan Wilcoxon Signed Rank test dengan tingkat signifikansi $\leq 0,05$. Hasil penelitian menunjukkan bahwa sebagian besar ibu hamil tidak mengalami nyeri punggung bagian bawah $83, \%$. Sedangkan uji statistik menunjukkan bahwa Senam hamil berpengaruh terhadap pengurangan nyeri punggung bawah dengan $\mathrm{p}=000$ dengan $\mathrm{p} \leq 0,05$.
\end{abstract}

Kata kunci : Nyeri Pinggang, Senam Hamil, Skala Nyeri.

\section{ABSTRACT}

One of the factors causing low back pain in pregnant women is pressure on the back muscles or a shift in the lower spine, this joint stress can be treated with pregnancy exercises for 30 minutes. The aim of this study was to know the effect of the development of pregnant gymnastic to reduce lower back pain in pregnant women. Pre-Experimental Research Design uses a test before and after in one group. The sampling method used Purposive Sampling. The sample consisted of 14 respondents in Sumberejo village, Banyuputih Situbondo sub-district in May. Data were taken from interviews and observations on pregnant women. Data were analyzed using the Wilcoxon Signed Rank test with a significance level of 50.05. The results showed that most pregnant women did not experience lower back pain $83 \%$. While the statistical test showed that pregnancy exercise has an effect on reducing low back pain with $p=000$ with $p \leq 0.05$.

Keywords: Low back Pain, Pregnancy Exercise, Pain Scale.

\section{PENDAHULUAN}

Angka kematian Ibu (AKI) tahun 2012 adalah 228/100.00 kelahiran hidup. Menurut (Depkes,2012) penyebab langsung kematian ibu yang terbanyak adalah perdarahan yaitu $28 \%$. Salah satu program dalam kesehatan yang efektif dalam mencegah morbilitas dan mortalitas ibu adalah dengan memberikan pelayanan kehamilan. Fungsi utama pelayanan kehamilan 
antara lain memberikan promosi dalam menjaga kesehatan selama kehamilan melalui sarana pendidikan kesehatan, yang diberikan secara mandiri maupun kelompok. Materi pendidikan kesehatan untuk ibu hamil cukup banyak, salah satunya senam hamil (Measure DHS, 2012).

\section{Tingginya AKI dapat} disebabkan oleh adanya penyulit dalam proses persalinan. Proses persalinan memerlukan persiapan dari ibu supaya dapat memperoleh persalinan yang aman dan lancar. Beberapa cara dilakukan untuk memperoleh persalinan yang aman dan lancar diantaranya persiapan sejak kehamilan. Senam hamil dilakukan untuk memperlancar proses persiapan persalinan yang dilakukan sejak kehamilan (Witjaksono, 2002).

Senam hamil memiliki banyak sekali manfaat diantaranya adalah dapat mengurangi rasa sakit saat persalinan, memperkuat otot-otot panggul sehingga dapat memperlancar dan mempercepat proses persalinan, memperkuat dan mempertahankan kelenturan otot-otot dinding perut dan dasar panggul yang penting dalam proses persalinan (Widiati, 2010).
Senam yoga merupakan program olahraga ringan dimana latihannya menggabungkan prinsipprinsip yoga. Yoga merupakan pendekatan secara holistic berupa fisik, mental dan spiritual yang melibatkan kombinasi peregangan otot tubuh, meditasi pernafasan, dan mendorong pertumbuhan kesehatan dan spiritual bila melakukannya. Gerakan dalam senam yoga dibuat khusus untuk melatih otot-otot uterus supaya menunjang ruang gerak janin di dalam kandungan. Dengan begitu, janin bisa berkembang dan bergerak secara optimal. Yoga juga membuat calon ibu lebih releks, dan kondisi ini baik untuk janin. Saat melakukan yoga seorang ibu harus merasa senang dan tidak stress, karena dapat merugikan ibu dan mengganggu pertumbuhan janin (Biljani, 2008).

Nyeri pinggang selama kehamilan adalah keluhan umum pada wanita hamil. Angkanya sekitar 50-70\% dari wanita hamil bias merasakannya. Nyeri pinggang ini bisa dirasakan di semua tingkat usia kehamilan. Tetapi paling banyak dirasakan saat kehamilan trimester II dan III (Dr,Didik K,2011). Dari hasil penelitian didapatkan dari 38 ibu hamil, 22 orang $(57,9 \%)$ ibu hamil 
mengikuti senam hail secara teratur mengatakan sudah tidak pernah mengalami pegal-pegal terutama nyeri pinggang jarang dirasakan , 16 orang $(42,1 \%)$ ibu hamil tidak teratur mengikuti senam hamil mengatakan masih sering merasakan pegal-pegal dan terkadang masih mengalami nyeri pinggang (Depkes Jatim,2013).

Senam hamil dan Yoga Antenatal bertujuan melatih otot panggul dan sekitarnya, agar menjadi lebih kuat dan elastis. Sirkulasi darah disekitar daerah panggul menjadi lebih lancar sehingga memudahkan ibu melakukan persalinan secara normal. Dengan latihan pernafasan yang dilakukan selama yoga, ibu akan terbiasa melakukan nafas pendek dan cepat dengan ritme yang teratur serta panjang dan dalam baik saat menghirup maupun melepaskan udara. Pelatihan nafas bisa menenangkan calon ibu untuk melalui rasa sakit dalam proses persalinan, serta memicu sistem saraf yang memperlancar pembukaan dan peregangan dinding vagina.

Senam selama masa hamil diperuntukkan bagi ibu hamil, oleh karena itu senam hamil mempunyai beberapa standar gerakan khusus yang disesuaikan dengan kondisi ibu hamil.
Beberapa tujuan senam hamil yaitu : (1) menjaga otot-otot persendian (2) memperkuat dan mempertahankan otot-otot dinding, perut, dasar panggul (3) meningkatkan kesehatan fisik dan psikis (4) menguasai tehnik pernafasan (5) mencegah varises. Dan beberapa manfaat dari senam hamil adalah : (1) mengurangi rasa sakit selama persalinan (2) mengurangi keluhan-keluhan selama kehamilan (3) memperkuat otot-otot panggul sehingga dapat memperlancarkan dan mempercepat proses persalinan (4) mengurangi stress, sakit dan nyeri (5) meningkatkan energi dan kekuatan.

Senam hamil dianjurkan untuk dilakukan selama 30 menit dalam seminggu dan ibu hamil hanya membutuhkan 3-5 kali senam hamil. Durasi senam hamil juga harus memperhatikan kondisi fisik dan kehamilan ibu.

Tujuan penelitian ini adalah untuk mnngetahui pengaruh pengembangan senam hamil yang dipadukan ddengan yoga antenatal untuk menurunkan lebih rendah nyeri punggung pada wanita hamil. 


\section{METODE PENELITIAN}

Penelitian ini menggunakan metode pra eksperimental design Sedangkan desain dalam penelitian ini menggunakan One Group PretestPosttest Design dengan analisis statistik Wilcoxon Signed Rank. Responden yang digunakan adalah ibu hamil trimester III di desa sumberejo sejumlah 14 orang dengan tehnik purposive sampling. Instrumen yang digunakan dalam penelitian ini yaitu Lembar observasi dan SOP senam hamil. Penelitian ini dilakukan di Desa Sumberejo dengan penilaian keterampilan pre menggunakan lembar observasi sebelum dilakukan perlakuan senam hamil.

\section{HASIL DAN PEMBAHASAN}

Pengaruh nyeri pinggang sebelum dilakukan senam hamil menunjukkan bahwa mayoritas ibu hamil yang mengalami nyeri pinggang dengan klasifikasi nyeri sedang 11 (78\%), dan sebagian kecil dengan klasifikasi tidak nyeri sebesar $0(0 \%)$. Sebagian besar responden yang mengalami nyeri pinggang setelah diberikan terapi senam hamil tiga kali di desa sumberejo Sukorejo Situbondo Tahun 2018, nyeri ringan 12 (85\%), tidak nyeri $0(0 \%)$, dan nyeri berat 0 $(0 \%)$.

Tabel.1.Frekuensi Nyeri Pinggang Sebelum dan sesudah Dilakukan Senam hamil

\begin{tabular}{clcccc}
\hline & & \multicolumn{2}{c}{ Sebelum } & \multicolumn{2}{c}{ Setelah } \\
No & Klasifikasi & \multicolumn{2}{c}{ senam } & \multicolumn{2}{c}{ senam } \\
& & n & $\%$ & n & $\%$ \\
\hline 1 & Tidak nyeri & 0 & 0 & 0 & 0 \\
2 & Nyeri Ringan & 2 & 14 & 12 & 85 \\
3 & Nyeri sedang & 11 & 78 & 2 & 14 \\
4 & Nyeri berat & 1 & 7 & 0 & 0 \\
& Jumlah & 14 & 100 & 14 & 100 \\
\hline
\end{tabular}

Tabel 1 Menunjukkan Pengaruh nyeri pinggang Pre dan post dilakukan senam hamil. Nilai mean ranks dengan uji wilcoxon hasil uji statistik nilai $\mathrm{p}$ value $0,000<0,05$ maka terdapat perbedaan keluhan nyeri pinggang yang bermakna antara nyeri pinngang sebelum dan sesudah dilakukan senam hamil dan yoga antenatal.

Hasil analisa ini sesuai dengan penelitian yang dilakukan Depkes Jatim, (2013) yang berjudul Pengaruh Pelatihan Senam Hamil Terhadap Pengurangan keluhan nyeri punggung bawah di Wilayah Kerja Puskesmas Kedungmungu Semarang. Hasil penelitian menyebutkan bahwa tingkat keluhan nyeri pinggang ibu sebelum dan sesudah mengikuti perlakuan senam hamil mengalami peningkatan 
dengan nilai rata-rata sebelum pelaksanaan pelatihan senam hamil adalah 57,9\% setelah pelaksanaan pelatihan senam hamil rata-rata adalah 8,20 terlihat nilai perbedaan antara pengukuran Pre dan post pelaksanaan pelatihan senam hamil.

\section{SIMPULAN DAN SARAN}

Simpulan penelitian menunjukkan terdapat pengembangan senam hamil dan pengaruh terhadap pengurangan keluhan nyeri Pre dan post senam hamil pada ibu hamil TM III di desa sumberejo Sukorejo Situbondo Bulan Mei 2018 dengan nilai exact sig (2 tailed) $=0,00$ dan nilai tersebut < taraf signifikan $(\mathrm{p} \leq 0,05)$.

Saran untu penelitian lebih lanjut sebaiknya menggunakan metode lain yang dapat mengukur pengembangan dan pengaruh senam hamil, hendaknya kegiatan serupa dilakukan juga di wilayah yang lain dan melibatkan beberapa institusi.

\section{DAFTAR PUSTAKA}

Depkes RI, 2009. Pedoman Pelaksanaan Kelas Ibu Hamil. Jakarta: JICA.

dr.Suwignyo Siswosuharjo, Sp. OG., M.Kes , 2010. Panduan Super
Lengkap Hamil Sehat. Jakarta: Penebar Plus .

Hidayat dan Mufdillah, 2008. Catatan Kuliah Konsep Kebidanan plus Materi. Yogyakarta: Mitra Cendikia Press.

Indriyani, 2011. Asuhan Kehamilan. Jakarta: Trans Info Media (TIM).

Mandriwati, G., 2011. Asuhan Kebidanan Antenatal: penununtun belajar. Jakarta: EGC.

Manuaba, 2010. Ilmu Kebidanan, Penyakit Kandungan dan KB. Jakarta: EGC.

Mufdillah, 2009. Panduan Asuhan Kebidanan Ibu Hamil. Yogyakarta: Nuha Medika.

Muhimah, N \& Safe'i, 2010. Panduan Lengkap Senam Hamil, Khusus Ibu Hamil. Jakarta: Power Book.

Saminem,Hajjah, 2006. Kehamilan Normal. jakarta: EGC.

Widianti, A.T. \& Proverawati, A, 2010. Senam Kesehatan. Yogyakarta: Nuha Medika. 